\title{
Feminist Lawyering and Legal Method
}

Kathryn Abrams

Catharine A. MacKinnon, Feminism Unmodified: Discourses on Life and Law. Cambridge, Mass.: Harvard University Press, 1987. Pp. 315.

Catharine A. MacKinnon, Toward a Feminist Theory of the State. Cambridge, Mass.: Harvard University Press, 1989. Pp. 330.

Recent events have conspired to prompt a broad reassessment of feminist theory's impact on law. A flurry of conferences on feminist jurisprudence have given activists an occasion to engage in self-scrutiny. Courses springing up at law schools nationwide have offered participants the chance to measure what has been won against the challenges that remain. Two recent books by Catharine MacKinnon have invited readers to consider the changes that moved her from the margins of a politically stymied group to the forefront of an intellectually vibrant movement.

Much of this retrospection has scrutinized feminism's impact on substantive laws in areas such as the workplace or the family. Only recently have scholars and activists begun to ask about feminism's impact on legal method: the ways in which legal inquiry is framed and legal arguments are made; the claims to know on which both are based. ${ }^{1}$ In most of this work,

Kathryn Abrams is an associate professor at Boston University School of Law, J.D. 1984, Yale Law School.

The author is grateful to Kate Bartlett and Steve Shiffrin for detailed and thoughtprovoking comments on a draft of this article, and to Bill Kell, Martha Minow and Susan Zeiger for conversations that contributed to the formulation of my arguments.

1. One of the first works to explore these questions in a comprehensive way is Katharine Bartlett's thoughtful article "Feminist Legal Methods," 103 Harv. L Rev. 829 (1990). Other works that discuss or raise methodological questions include Martha Fineman, "Challenging Law, Establishing Differences: The Future of Feminist Legal Scholarship," 42 Fla. L Rev. 25 (1990); Deborah Rhode, "Feminist Critical Theories," 42 Stan. L. Rev. 617 (1990); Martha Minow, "Beyond Universality," 1989 Chi. LF. 115. 
however, the emphasis has been on the methods of the legal scholar: The impact of feminism on the methods of lawyers ${ }^{2}$ - those who work for legal change in the courts, legislatures, and other public forums-is only now beginning to be explored. The belatedness of this inquiry may seem peculiar-feminist lawyers have been advocating feminist-inspired legal change for many years now-but it may be explained by several factors.

First, many observers may not expect that a movement for legal reform will scrutinize and challenge legal method. The civil rights movement, probably the most prominent of such movements, made brilliant instrumental use of the law by accepting many of its substantive and methodological premises and using them to reveal the system's inconsistency. The NAACP's long, carefully planned march toward Brown held the legal system not only to its promise of formal equality but also to its respect for precedent and practice of argument by analogy. ${ }^{3}$ Schooled by this successful example, observers may not look for legal reformers to recast their tools as they use them to craft new social institutions.

Second, some commentators who have perceived the feminist challenge to lawyering method have viewed it as problematic for the movement. "How do you persuade as a feminist lawyer?" Christina Whitman asked in a recent essay on MacKinnon's book, "Must you choose between

2. It is important not to overdraw the distinction between the methods employed by legal scholars and those employed by lawyers. As I will argue, many of the methodological and epistemological assumptions that shape feminist lawyering had their origins in feminist legal theory. However, for purposes of distinguishing my inquiry from those that have come before, I would offer the following comparison. Katharine Bartlett's emphasis, for example, differs from my own in that she asks what methods feminists (as legal scholars and activists) have used to challenge the law's exclusion of different elements of women's perspectives, and what kinds of claims of truth are implicit in these methods, whereas I ask how feminists (as legal activists) have argued, organized themselves, and understood their relationship to other legal actors in their efforts to produce social change. Other recent works that have raised the question of lawyering method include Ruth Colker, "Feminist Litigation: An Oxymoron?-A Study of the Briefs Filed in Webster v. Reproductive Health Services," 13 Harv. Women's LJ. 137 (1990); Sarah Burns, "Notes from the Field: A Reply to Professor Colker," 13 Harv. Women's LJ. 189 (1990); Elizabeth Schneider et al., "Lesbians, Gays and Feminists at the Bar: Translating Personal Experience into Effective Legal Argument," 10 Women's Rts. L. Rptr. 107 (1988); Naomi Cahn, "Defining Feminist Litigation," 14 Harv. Women's LJ. (forthcoming 1991). For a thought-provoking use of literature to reflect on the feminist lawyer's role, see Jane Cohen, "Feminism and Adaptive Heroinism: The Paradigm of Portia as a Means of Introduction," 25 Tulsa LJ. 657 (1990).

3. The civil rights movement did produce some notable innovations in legal practice, although they did not often take the form of a conscious challenge to method. See Owen Fiss, The Civil Rights Injunction (Bloomington: Indiana University Press, 1978); Abram Chayes, "The Role of the Judge in Public Law Litigation," 89 Harv. L. Rev. 1281 (1976). In characterizing the legal program of the movement, several contemporary legal scholars have identified both preservative and revisionary strains in the movement's approach to legal conceptualization and argumentation. See Milner Ball, "Stories of Origin and Constitutional Possibilities," 87 Mich. L. Rev. 2280 (1989); Kimberlé Crenshaw, "Race, Reform and Retrenchment: Transformation and Legitimation in Antidiscrimination Law," 101 Harv. $L$. Rev. 1331 (1988); Patricia Williams, "Alchemical Notes: Reconstructing Ideals from Deconstructed Rights," 22 Harv. C.R.C.L. L. Rev. 401 (1987). 
a language of neutrality, which provides credibility but disables you from saying those things you most need to say, and a feminist language, which allows you to say those things at the cost of being believed?" 4 The assumption that methodological innovation may create temporary problems of legitimacy is not unfounded. The conventional forms of legal persuasion, for example, are part of a system that was created by and for male lawyers; deviation from these forms may enhance the perception of mainstream decision makers that feminist arguments are peculiar or foreign.

Yet to assume a chronic tension between "feminist method" and "legal method" that ultimately condemns the former to failure seems both pessimistic and oddly static. Legal method, however male-identified its current incarnation, is not some brooding omnipresence in the sky. It is, rather, a partly cohering collection of professional practices and argumentative conventions employed by those who make their livings as lawyers. While feminist lawyers may be temporarily delegitimized by their departures from methodological conventions, their participation in the legal system also contributes to the ongoing reformulation of those conventions. Over time, if feminist advocates remain persistent and grow numerous, they may transform not only lawyers' views of gender justice, but their views of how to use law to persuade and produce social change.

In this essay, I will explore on the impact of feminism on the methods of its legal advocates. ${ }^{5}$ While it is too early, and this inquiry too limited, to

4. Christina Whitman, "Law and Sex" (review of C. MacKinnon, Feminism Unmodified), 86 Mich. L. Rev. 1388, 1389 (1988). For an even stronger argument that law as a "dominant discourse" threatens to "transform feminism," see Fineman, 42 Fla. L Rev. at 30.

5. I want to stress here that I have chosen to look at feminist lawyers rather than women lawyers. There is a body of literature concerning the legal profession that draws on the insights of Carol Gilligan to suggest that the socialization of women may encourage a moral orientation toward care which has not previously exerted substantial influence over the way that lawyers approach their task, and which may, as women increasingly enter the profession, infuse and shape the practice of law. See, e.g., R. Jack \& D. Jack, Moral Vision and Professional Decisions: The Changing Values of Women and Men Lawyers (Cambridge: Cambridge University Press, 1989); Carrie Menkel-Meadow, "Portia in a Different Voice: Speculation on a Women's Lawyering Process," 1 Berkeley Women's LJ. 39 (1985). Although 1 discuss Menkel-Meadow's work infra at text at nn.57-58, this essay does not ask about the methods of women lawyers but rather about the methods of feminist lawyers; I make this choice for several reasons. First, I am not fully convinced that one's socialization "as a woman" produces a particular orientation toward moral decision making. At the very least, I believe that speaking of socialization "as a woman" ignores important distinctions among subgroups of women that undoubtedly affect orientation toward moral decision making. Second, being a biological female or even being "socialized as a woman" seems to me less likely to affect the way one practices law than being a feminist. Even if one were to posit some distinct "female" socialization, it is not inevitable that the perception of a tension between personal and professional socialization would lead most women to reform the profession. The perception of women lawyers that they are responsive to a different moral orientation could instead lead them to try to change their personal orientation or to leave the profession. In fact, some empirical and theoretical work suggests that these latter responses are more frequent. See Jack \& Jack, Moral Vision at (roughly) 130-70; Joan Williams, "Deconstructing Gender," 87 Mich L Rev. 797 (1989). Being a feminist, on the 
assess its impact across the profession, it is both timely and instructive to consider some of the innovations feminist lawyers have been attempting. In so doing, I will use the terms "method" or "lawyering method" to designate three related aspects of the way that feminist lawyers approach their professional task. The first set of questions encompassed by my definition are those traditionally associated with the term "legal method": what does the lawyer regard as the elements of persuasion? In what terms does she frame her arguments and how do these terms relate to the traditional norms of legal persuasion? The second element of my inquiry looks beyond the immediate task of persuasion to the larger set of efforts required to produce legal reform. Feminist lawyers are law reformers: they seek not simply to secure sound outcomes under the existing law, but to correct the law in favor of its own incompletely expressed aspirations or a set of externally generated norms. How they attempt to bring about these changes constitutes a second important field of inquiry. From what position do they critique the existing legal structure, and on what sources do they draw to generate new legal responses? How do these sources differ from those of previous law reformers? To what audiences and institutions do feminist lawyers address their demands for reform? A third and final set of questions concerns the feminist lawyer's conception of the roles and relationships among legal actors. Certain norms of the judicial role may make it difficult for judges to hear or credit feminist lawyer's arguments; certain relationships among lawyers or between lawyers and clients may be inconsistent with elements of the feminist critique. How feminist lawyers have attempted to redefine legal roles in order to advance, or implement, their substantive position is a final question my analysis will survey.

In attempting to answer these questions, I will look at works or contexts in which feminists are acting within the legal system to produce social change. By making this qualification, I do not mean to rehabilitate the dichotomy between theory and practice effectively eroded by feminist advocates. Moreover, most of the feminists whose advocacy I will discuss are academics as well as lawyers, who see their work in these roles as deeply related. But the writings I will examine are specifically addressed to actors within the legal system-lawyers, prospective lawyers, judges-as well as to legal academics. They advocate particular changes in the law, unveil new strategies of lawyering and of judging, describe the struggle for feminist law

other hand, does not simply mean having been shaped by the distinct forms of socialization or discrimination that women suffer in a gendered society. It also means having developed a critical agenda for change in society that "originat[es] in the experiences of gender subordination." Bartlett, 103 Harv. L Rev. at 834. For a fuller discussion and critique of this usefully broad definition, see id. at 833-36. The kind of critical understanding and resolve to seek change that inheres in the latter part of this definition suggests that the smaller group of feminists who are lawyers are more likely to take a critical or reformist stance toward the methodological norms of their profession than are the larger group of women who are lawyers. 
reform from the inside. And the effects I hope to trace are not only in the way we conceive the world as legal academics but in the way we strategize and argue as lawyers.

\section{MACKINNON: DOMINANCE AND METHOD}

An appropriate starting point for any discussion of feminist lawyering is the work of Catharine MacKinnon. Not only has she been one of the earliest and most successful legal advocates for women. But in the scope and framing of her vision and the variety of roles she has espoused to promote it through law, she challenges many of the traditional norms of legal method and practice. New insights into her method and message are provided by two recently published books: Feminism Unmodified (hereafter "FU"), a collection of speeches on various topics germaine to feminist legal change, and Toward a Feminist Theory of the State (hereafter "FT"), a sustained theoretical presentation of her feminist theory, including a focus on such specific problems as rape, abortion, and pornography.

MacKinnon derives her program through a method she describes as "feminist"; it is only after she has developed her substantive perspective by this method that she advances it through the uneasy borrowing of legal tools. ${ }^{6}$ If MacKinnon seeks to keep her feminism "unmodified" by any qualifying affiliation, ${ }^{7}$ she also wants to preserve it from revision by the methods of other movements or disciplines. Christine Littleton has described MacKinnon's feminist method as having two components: "believing women's accounts" of their lives; and understanding that these accounts reveal "sexual use and abuse by men" (FU at 5). ${ }^{8}$ In Toward a Feminist Theory of the State, MacKinnon provides perhaps the fullest elaboration to date of both elements.

Women, MacKinnon claims, came to trust their own accounts of their experience through the activity of consciousness raising (FT at 85-105). As groups discussed subjects like sexuality, power, and family, similar

6. Responding to the question of how advisable it is for feminists to use the maleconstructed legal system to advance their goals, MacKinnon states (in FU at 228): "The question then becomes not whether one trusts the law to behave in a feminist way. We do not trust medicine, yet we insist that it respond to women's needs. We do not trust theology, but we claim spirituality as more than a male preserve.... If women are to restrict our demands for change to spheres we can trust, spheres we already control, there will not be any."

7. For a thought-provoking discussion of the reasons why MacKinnon rejects the notion of distinctions among, or a pluralism of, feminists see Christine Littleton, "Feminist Jurisprudence: The Difference Method Makes," 41 Stan. L. Rev. 751, 754-63 (1989).

8. See Littleton, 41 Stan. L Rev., at 764, 771. The second element highlights the ubiquitousness of women's sexual objectification by men; it also stresses the connection between the pervasive, almost invisible instances of "use" and the more extreme examples of sexual violation we have been socialized to regard as "abuse." 
strains in many women's narratives "confirmed awarenesses they had hidden, including from themselves" (id. at 87). Women discovered that they were not alone in their feelings and that they were not crazy; but they also came to view their lived experience as a source of knowledge about the world.

When one understands that consciousness raising established a new way of knowing, it becomes easier to see why it has been so difficult for many people to believe women's accounts. An epistemology which stresses "women's consciousness, or lived knowing, of [their] situation" (id. at 95) is inaccessible to, and devalued by, those who favor the objectivity and distance of scientific epistemology (id. at 97). The scientific epistemology, which MacKinnon describes as establishing a set of qualities men value as the universal determinants of validity, is not, of course, universal. But it has been so pervasively embraced by those with the power to control social meanings that it appears to be universal. This problem-the invisible grip of male epistemology-makes clear why the injunction to "believ[e] women's accounts" does more than bring their lives into the light. Because this approach insists on a feminist way of knowing, it removes "objective" knowing from its ontological guise and reveals it as a perspectival epistemology elevated by male power (id. 237-38).

Having learned to credit the epistemological form of women's accounts, it remains to discover their content. This MacKinnon describes as "the reality of sexual abuse":

It combines women's sex-based destitution and enforced dependency and permanent relegation to disrespected and starvation-level work ... with the massive amount of sexual abuse of girls apparently endemic to the patriarchal family, the pervasive rape and attempted rape about which nothing is done, the systematic battery of women in homes, and prostitution ... of which the pornography industry is an arm. (Id. at 242)

MacKinnon's claim that women's experience displays this unitary pattern has been one of the most controversial elements of her feminist theory. With Feminism Unmodified, MacKinnon sparked a heated debate not only by insisting on this unitary interpretation but by suggesting that those who dispute it could not accurately describe themselves as feminists. ${ }^{9}$ In Toward a Feminist Theory of the State, MacKinnon considers at substantial length what she describes as "authority of interpretation" (FT at 115-21).

9. Among the most hotly contested statements is the assertion that women who regard pornography as raising First Amendment issues are "defending a source of their relatively high position among women under male superiority," $F U$ at 205 . In a particularly vituperative passage, MacKinnon tells these women to "stop claiming that your liberalism, with its elitism, and your Freudianism, with its sexualized misogyny, has anything in common with feminism." Id. 
MacKinnon asks how feminists should view the accounts of "rightwing women and lesbian sadomasochists," who claim to find satisfying or even "authentic" sexual experience in relationships based or patterned on male domination (id. at 115). There appear to be no easy answers. A "false consciousness" argument is flawed because it claims authority on the basis of an impossible objectivity, a removal from the "unconscious conditioned reflections of oppression" (id.). Crediting any biological woman's perspective is no better, because "it assumes that women have power and are free in exactly the ways feminism has found they are not" (id.). Women's situation provides neither an objective ground to stand on nor a distinctive, wholly owned subjectivity to retire to, because "few if any aspects of life are free of male power" (id. at 116). ${ }^{10}$ Thus the claim that it is possible to describe "authentic" female sexual experience, or the "essential" characteristics of women, makes no sense in a world where women's qualities and perspectives are the product of domination. Yet, if this domination makes it difficult to offer "essential" descriptions of women or their experiences, it does not prevent women from identifying the salient features of their political situation. Through feminist epistemology, women glimpse not their essence, but the structure of power under which they live. As MacKinnon states: "To say that the personal is political means that gender as a division of power is discoverable and verifiable through women's intimate experience of sexual objectification, which is definitive of and synonymous with women's lives as gender female" (id. at 120).

Armed with these insights into women's condition, MacKinnon turns to the law. Her approach is justifiably wary. "Liberal legalism," she notes, makes "male dominance both invisible and legitimate by adopting the male point of view in law at the same time as it enforces that view on society" (id. at 237). Yet these qualities in the law can, paradoxically, be a source of strength. When women examine positive law with the understanding that "male forms of power over women are affirmatively embodied as individual rights in law" (id. at 244), they begin to glimpse the constructs that need to be changed."

MacKinnon's view of law as a menacing, if malleable, instrument also extends to the elements of legal method. The practice of relying on precedent, or granting authority to objectivity, reflects male perspectives that can modify the insights produced by feminist method. It is therefore necessary for feminists using the law to rethink even the conventions of legal

10. The correlate of this proposition is that "[n]either the transcendence of liberalism nor the determination of materialism works for women." Id. at 117.

11. The defense of "mistaken consent" in the law of rape, for example, is simply a legal embodiment of the perspective of the perpetrator; it should be eliminated as a violation of women's equality "because it takes the male point of view on sexual violence against women" (FT at 244). 
argumentation. This methodological revisionism is clear in the oral advocacy of Feminism Unmodified.

First, the sources of authority on which MacKinnon bases her arguments reflect little deference to existing legal categories or disinterested observation. Existing categories are suspect, largely because they are extant: like the First Amendment doctrine that forms her primary example, they reflect a male supremacist logic that takes no account of the perspectives of women. The perspective of the "impartial observer" is not respected but reviled: it reflects the view of those who enjoy the power to make their subjectivity the "objective" norm; it not only excludes but discredits the views of women who have never enjoyed such power. Paradoxically, legitimate support for legal claims comes mainly from a source that has heretofore been excluded or discredited: the experience of women whose accounts of "use and abuse" are characteristic of women's current situation.

Similarly, MacKinnon is wary of argument by analogy or increment. While she may note in passing a similarity between the claim of women and another group, ${ }^{12}$ she stresses the singularity of gender oppression as a political phenomenon, ${ }^{13}$ as well as the fact that her arguments exposing and combatting it have "never [been] heard before" (FU at 127). She attempts to persuade not by invoking legal or normative assumptions that we are already inclined to make, but by presenting a comprehensive, radically conflicting account of reality. ${ }^{14}$ She attempts to make this account authoritative for her audience by suggesting that they have had experiences or intuitions that are reflected in or lead inexorably to this account. ${ }^{15}$ MacKinnon may also try to persuade audiences that her account is so unitary, so consistent and extensive in its reach, as to be more credi-

12. She suggests, for example, that Jews are victimized and silenced by Nazi speech, and blacks by Klan speech, much as women are victimized by pornography. FU at 209.

13. MacKinnon notes that "Idloing something legal about a situation that is not really like anything else is hard enough in a legal system that prides itself methodologically on reasoning by analogy." Id. 167 .

14. However, MacKinnon does occasionally employ analogy, and those occasions are useful to consider. First, she sometimes analogizes from one feature of her comprehensive account (particularly one already accepted by the legal system) to another. For example, she sometimes compares the MacKinnon-Dworkin antipornography ordinance, which conceives pornography as a violation of women's civil rights, to the claim under Title VII, which characterizes sexual harassment as a violation of women's civil rights. See FU at 198. Second, she sometimes analogizes from women's oppression to the oppression of another group (rather than vice versa), often in a way that suggests that the legal treatment of the second group is flawed as well. See supra note 12 (suggesting Jews should have been regarded as victims of Nazi speech). Finally, on comparatively rare occasions, MacKinnon analogizes to established legal arguments or categories, but this is only when necessary to establish the constitutionality of her remedial legislation. See FU at 177 (describing definition of pornography under Minneapolis Anti-Pornography Ordinance as "a medium-message combination that resembles many other such exceptions to First Amendment guarantees").

15. The most memorable version of this attempt occurs in her first lecture, "Not by Law Alone: From a Debate with Phyllis Schlafly," (FU at 29), where she suggests to Phyllis 
ble than other accounts of the politics of gender. As befits a proponent of radical revision, MacKinnon shows little of the conventional jurist's fear of the "slippery slope." Warned that the difficulty of drawing lines under the antipornography ordinance would threaten large categories of now-protected speech, MacKinnon notes grimly that this is no surprise, given the pervasiveness of pornographic expression and representation (id. at 131, 154). She grasps such arguments to help her demonstrate the scope of the problem, even when they suggest the difficulty of remediation within the current legal framework.

Yet to focus on such elements gives only a partial view of MacKinnon's feminist legal innovations. The features discussed above are, in large part, those associated with litigation; and litigation comprises only a part of MacKinnon's approach to feminist lawyering. Much of MacKinnon's work has involved establishing the preconditions that make litigation useful to women-drafting antipornography ordinances ${ }^{16}$ or creating claims for sexual harassment under Title VII. ${ }^{17}$ However, by taking on the role of legal architect, MacKinnon does not simply facilitate litigation; she recreates it in the image of feminist method. When MacKinnon drafts an ordinance or argues for a new kind of statutory claim, she is able to derive her formulations from women's experience and can thus achieve the greatest possible distance from male-designed legal categories that deny such experience. ${ }^{18}$

MacKinnon's legislative products are also distinct from standard prohibitory legislation in that many of their most important addressees lie beyond the circle of immediate perpetrators. The claims target particular practices in a way that illuminates for society as a whole the larger problem of sexual subordination. The contribution of MacKinnon's work on sexual harassment was not merely making it actionable but showing that it is

Schlafly that Schlafly was in fact victimized by a male supremacist administration when she was passed over for a job in the Defense Department.

16. With Andrea Dworkin, MacKinnon has drafted and sponsored municipal antipornography ordinances in Minneapolis, Minn., Indianapolis, Ind., and Cambridge, Mass.

17. Two new claims ("quid pro quo" and "hostile environment") against sexual harassment under Title VII arose in part from the influence of MacKinnon's work. See, e.g., Bundy v. Jackson, 641 F.2d 934 (D.C. Cir. 1981).

18. In her influential work, Sexual Harassment of Working Women (New Haven: Yale University Press, 1979) ("MacKinnon, Sexual Harassment"), MacKinnon examines women's experiences of harassment and draws from these accounts both her characterization of sexual harassment as a form of sex discrimination and her view of the circumstances under which it should be actionable. Mackinnon's view of pornography as an example and a source of sexual subordination was formed through exposure to the accounts of its victims. The Minneapolis ordinance she and Dworkin drafted to curtail it was preceded by a lengthy, wrenching set of hearings in which victims of pornography told their stories to legislators and the public. See Paul Brest and Ann Vandenberg, "Politics, Feminism and the Constitution: The Anti-Pornography Movement in Minneapolis," 39 Stan. L Rev. 607, 617-29 (1987). 
not "flirtation" or "mutual attraction" but a form of sex discrimination. 19 The Minneapolis ordinance similarly depicts pornography not as protected speech but as an act that objectifies-and sexualizes the objectification of-women.

These statutes also address women in a way that seeks to transform their view of themselves. By creating causes of action for injuries that have been made invisible, they credit subjective experiences that women themselves may have come to doubt. They also allow women to sue on their own behalf, enabling them to view themselves, at least in this context, as the subjects of their own lives rather than the objects of others' constructions. The variety of claims available in each context, and the breadth of "anti-trafficking" and "hostile environment" claims permit women to rely on their own intuitions rather than on preexisting categories in deciding when an injury has occurred.

The very qualities that distinguish MacKinnon's work as a drafter, however, complicate her task as an advocate. The comprehensive, radical messages communicated by these claims are rarely self-enforcing; on the contrary, their discordant themes are constantly threatened by the pervasiveness of conventional understanding. Potential claimants begin to doubt that they have been subordinated by trafficking in pornography; courts begin to confuse harassment with flirtation or vulgarity; all addressees miss the connection between these offenses and rape, domestic violence, and other symptoms of sexual subordination. If these claims are to be effective tools in curtailing offensive practices, and if their more comprehensive messages are to be understood, they must be reinforced by the kind of persistent consciousness raising from which they arose. Thus the creation of new legal claims gives rise to a third component of MacKinnon's legal advocacy: public speech on behalf of feminist-inspired legal change.

This is nowhere clearer than in the text and context of Feminism Unmodified. In this work, MacKinnon displays her strategy for uniting these apparently disparate realms of women's experience. She speaks to and with audiences-about women's lives, gender wrongs, legal remedies-in a great variety of settings. The conclusion that flows from this lengthy dialogic journey is that there is no context that is not ripe for the message of gender oppression, and no group of women who remain untouched by one or more of its invidious arms. There is also no hope for legal change without a constant, passionate reexamination of why we need it. These speeches, presumably about law, mention its remedies only intermittently. More prominently they are about the numerous, interrelated manifestations of gender oppression in women's everyday lives. They inspire legal

19. See MacKinnon, Sexual Harassment, 1-7. 
change less by advocating specific reforms than by depicting the fearsomely pervasive problem that makes reform imperative.

There is much in MacKinnon's work that holds out promise for a distinctive, feminist approach to lawyering. Her example is a bracing antidote to works which suggest the inevitable, homogenizing influence of legal education and practice. MacKinnon, in contrast, conveys the message that lawyers can interpret reality and even develop political-legal programs by reference to methods not derived from law; that they can be eclectic in their use of the law, exploiting its strengths without assimilating all its assumptions. She suggests that it is possible to question the virtually sacrosanct bases of legal persuasion, and substitute such new building blocks as experiential argument or comprehensive juxtaposition of alternatives. She shows that the "role demands" of the lawyer are not something set in stone, but are, rather, capable of being shaped by one's commitment and one's talents. In her hands, the role of the lawyer becomes that of a dazzling polymath-litigator, creator of transformative legislation, public speaker-and a member not of some fraternity of abstract right but of the subordinated community she attempts to empower.

There is a sense, however, in which the promise of MacKinnon's innovations exceeds what she is able to deliver. There is a rigidity to her vision of women's situation and her approach to changing it that has consequences not only for her theory but for her role as a feminist lawyer. This rigidity makes Mackinnon difficult to emulate: Many feminist lawyers who admire her work have found it virtually impossible to take her as a practical role model. But more important, this rigidity limits the range of the methodological transformation she is able to produce. We can glimpse these limits by starting from two features of MacKinnon's approach: her conviction that women's experience can be understood only as "use and abuse" and her insistence on using her analytic framework as the sole point of reference in discussion.

At heart of MacKinnon's methodological innovation is a unitary perspective on women's experience: that "believing women's accounts" reveals "sexual use and abuse by men." Liberal legalism in all its professional guises would not be suspect if it did not conceal this truth. Yet MacKinnon's unitary proposition does not resonate with all facets of many women's experience; it does not tell us whether we should "believe" women's accounts that do not point inevitably to "use and abuse." MacKinnon's argument about authoritative interpretation is her most sustained attempt to deal with this tension, and it is in some respects illuminating. It explains why a feminist perspective arises from neither subjectivity nor objectivity, why it is distinct from liberalism or materialism. It indicates why we should be suspicious of efforts to describe such matters as "women's sexuality" in a noncontingent way. It does not, to this reader, provide a 
satisfying answer to the problem of dissenting accounts of women's experience.

Think about the right-wing women and lesbian sadomasochists whose accounts of sex conflicted with MacKinnon's (we might also add liberal feminists and others whose lives do not support MacKinnon's claims of systematic abuse). The question is not whether these dissenters offer an "essential" or noncontingent characterization of women's experience. It is whether we should "believe [their] accounts" as well as those documenting use and abuse; whether these experiences provide insights we should use in formulating or evaluating a feminist theory. MacKinnon never responds affirmatively to these questions, but the nature of her negative response has tended to vary. In Feminism Unmodified she describes such dissenting perceptions as being wrong, either morally or epistemologically; in Toward a Feminist Theory of the State, she describes these views either as impossible or as the product of flawed understanding. In one section, MacKinnon states that "[e]pistemologically speaking women know the male world is out there because it hits them in the face. ... It has all the indeterminacy of a bridge abutment hit at sixty miles per hour" (FT at 123). In another, she asks: "[w]hen women engage in ritualized sexual dominance and submission with each other, does that express the male supremacist structure or subvert it? ... [T] [Te answer for gender depends upon whether one has a social or biological definition of gender and sexuality" (id. at 119).

This last statement raises the question of whether MacKinnon has actually avoided the claim of "false consciousness." Frances Olsen has redirected debate over this issue by suggesting that MacKinnon's rejection of dissenting accounts is partly strategic. ${ }^{20}$ Without contesting the power of Olsen's explanation, I want to take MacKinnon at her (critical) word. MacKinnon's discussions suggest to me at least three different ways in which she may view dissenting accounts of women's experience.

First, dissenters may have somehow managed, biology notwithstanding, to escape the experience of being "gender female" in our society. Although it seems unlikely, given the pervasiveness of subordination in our society, MacKinnon suggests that there are some women whose comparatively privileged position permits them to ignore those ways in which they have been subject to use or abuse (FU at 70-77). Second, dissenters may have suffered the experiences of use and abuse but have not been

20. "Feminist Theory in the Grand Style" (reviewing MacKinnon, Feminism Unmodified), 89 Col. L. Rev. 1147, 1175-77 (1989). By arguing that MacKinnon's view of dissenting accounts may be less harsh than her public statements suggest, Olsen has decreased the urgency of questioning whether these condemnations amount to "false consciousness" claims. For a discussion of whether this "strategic" interpretation ameliorates the dangers of "false consciousness" claims by MacKinnon and other feminist scholars, see Kathryn Abrams, "Ideology and Women's Choices," $24 \mathrm{Ga}$. L. Rev. 761 (1990). 
exposed to whatever analog to consciousness raising permits them to understand what they have lived. Perhaps the subordination imposed on women is readily perceptible only if women have had some experience that permits them to trust their own accounts. MacKinnon's chapter on consciousness raising suggests that such an experience was necessary during the 1960s and 1970s to help women as a group understand what they were experiencing. It is not clear whether she believes that this experience needs to be recreated for contemporary groups of women in order for them to understand what she claims they "know." Because of the greater visibility and comprehensibility of feminist epistemology today, MacKinnon may expect her audiences to share this understanding without elaborate preparation. On the other hand, maybe MacKinnon's continuous public speaking may represent an effort to provide the kind of setting in which women can come to trust their own accounts. Finally, some women may understand their experience to be one of abuse but make a choice in favor of willful complicity in patterns of male domination-including denial of any controversial characterization of their experience. Unlike the others, this view may reflect not "false consciousness" but a domination pervasive enough to make some women see the futility of insisting on their own perceptions of reality.

These three alternatives offer different explanations of dissenting accounts and raise different possibilities for feminist organizing and persuasion. Yet they share one salient feature: None of them credits, or takes as authoritative for the purpose of theory building or political change, a dissenting perspective on women's experience. Although she claims that there are no "universal" perspectives, MacKinnon's view of women's experience is still the sole building block for feminist transformation. Several feminist scholars have decried the theoretical implications of this unitary vision, in particular the fact that it attempts to "control and objectify her subject [in a way] that is characteristic of the male world" she attacks. ${ }^{21}$ I want to consider instead the problems MacKinnon's rigidity of vision creates for her as a feminist lawyer-as a methodological innovator and an advocate for social change.

The first problem is that MacKinnon's rigidity on the nature of women's challenging methodological reforms. This is an ironic twist on the problem with which I opened. It is not simply that (nonfeminist) lawyers will disregard the message because of the method by which it is presented, but that (feminist) lawyers may view with suspicion the methodological innovations MacKinnon offers because of the monolithic message with which they are associated. To some extent this latter rejection is inevitable, even appropriate: if you don't believe that women's experience, in

21. See Katharine Bartlett, "MacKinnon's Feminism: Power on Whose Terms?" 75 Calif. L. Rev. 1559, 1564 (1987). 
life and under law, is marked by an odious and systematic oppression that few have recognized, you may not find it appealing, for example, to abandon precedent as a source of authority. Yet to reject, or neglect, all of MacKinnon's innovations because one disagrees with her account of women's lives would seem to be a mistake. Women who do not share MacKinnon's view of their situation may benefit, for example, from her message that we can challenge and change dominant norms by drafting prospective legislation derived from the experiences of women.

Second, MacKinnon's insistence on a single account of women's experience complicates her efforts to coalesce with others-an activity many view as essential to producing comprehensive political change. Coalescence with MacKinnon may seem difficult not only to women who reject her account of women's experience (the tag of "collaborator" has rarely motivated anyone to seek political alliance) but also to women who are unacquainted with MacKinnon's views or whose experience differs from hers along axes unrelated to gender. At a time when many feminists highlight the diversity of their community, MacKinnon approaches racial and ethnic minorities by assimilating their experiences to her own account. A disturbing, though complicated, example is a speech to a group of Native American women, in which MacKinnon discusses the case of Martinez $v$. Santa Clara Pueblo. ${ }^{22}$

Martinez challenged a Pueblo tribal rule, which prevented women who married out of the tribe from passing their rights in its common land to their children. Starting from the opinion of the Supreme Court, which held the issue to be a matter of tribal sovereignty, MacKinnon discusses the world of gender relations that the Pueblo might create for themselves. MacKininon examines the Pueblo rule in its cultural context: as an effort to protect Indian lands from a white male supremacist threat. She criticizes the Pueblo framers of the rule, both for sexism and for the failure to respect members of their own tribe (FU at 68 ). Yet when she considers a new tribal rule regarding gender, the choices seem strikingly familiar, despite the distinctiveness of the culture. Native American women and their tribes can, on the one hand, elect a continuation of sexism-which MacKinnon claims some Indian cultures learned from European men (id at 69). They, on the other hand, embrace "the aspiration to be no less than men ... which is indigenous to women across place and across time" (id. 28).

MacKinnon's argument links sexism and imperialism and makes

22. 436 U.S. 49 (1978). The discussion of this case occurs in FU at 63-69. While working on the final draft of this essay, I discovered a similar discussion of Mackinnon's treatment of the Martinez case in Angela Harris' article, "Race and Essentialism in Feminist Legal Theory," 42 Stan. L Rev. 581, 593-95 (1990). I recommend Harris's discussion, and the rest of her superb article, to anyone interested in the racial solipsism implicit in MacKinnon's thought. 
white men responsible for both. It suggests that the path to Native American sovereignty lies in treating women equally. And it implies that equal treatment for women is some sort of a cross-cultural constant. There is undoubtedly support for some of these claims, ${ }^{23}$ but the way MacKinnon deploys them is solipsistic and even manipulative. By carefully skirting the question of whether there are distinctive forms of Native American sexism, she blurs the boundaries between Native Americans and feminists. She further induces Native Americans to become feminists by suggesting that they can fight their battle by fighting hers. In her analysis of a people whose culture is unique and whose oppression is tragically distinct, MacKinnon manages to assert that sexism is at the root of everyone's problems. And the awareness of Native American culture that she uses to elicit her audience's support seems to have little role in the changes the proposed coalition would seek together.

Finally, MacKinnon's unitary view of women's experience limits the extent of methodological innovation that follows from her ostensibly epistemological claim. The method of knowing through lived experience would seem to point to many new methods of legal persuasion. Not only would there be a range of experiences on which women could draw in revising law to take account of their lives, but shared experience might help in establishing a human connection between lawyer and client, or lawyer and judge; and it might encourage procedural reforms that permit women to tell, and fact finders to credit, their stories. MacKinnon follows none of these paths in her discussions of feminist legal change; at least some of the reasons are not far to seek. Experiences beyond "use and abuse" would seem to be of dubious value in promoting MacKinnon's feminist legal change; experiences shared with those in power ought to elicit our skepticism; and rules facilitating the telling of women's stories would seem less important when the gist of those stories can be fairly easily captured. Invocation of women's experience ultimately seems to be less of an epistemological innovation than a route to the thesis of "use and abuse."

The rigidity implicit in MacKinnon's approach, moreover, extends to more than her view of women's experience. Equally restrictive of MacKinnon's feminist lawyering is her reluctance to elaborate her theory in ways that make it accessible to her audience. ${ }^{24}$ In her "Afterword," to Feminism Unmodified, she pays gracious tribute to her audiences as "those whose

23. White American men have been guilty, sequentially and simultaneously, of sexism and imperialism. It is also true that some social problems that hinder Native American tribes were originally instigated by European settlers. See M. Dorris, The Broken Cord (1989) (arguing that some Native American tribes learned excessive drinking habits from French trappers).

24. As I will explain, this reluctance has several manifestations, including a refusal to speculate in any systematic way to the features of the world that feminists will create, and a rejection of any effort to reframe her argument to reach audiences who may not share or understand her premises. 
mental aliveness elicited these thoughts in this particular form" (id. at 215) and states that "even if [words] are later written down as one person's delivery[, a]s a form, speaking remains dialogue" (id.). Reading the later record, one wonders if MacKinnon's audience shares her view. If MacKinnon rarely offers hostile listeners the news they want to hear, she equally rarely offers sympathetic audiences the information they need to proceed. She resists analogies, ${ }^{25}$ brushes aside the barriers created by existing legal doctrine, ${ }^{26}$ speaks disparagingly about the possibilities of persuading judges, ${ }^{27}$ and declines to speculate about subjects from the nature of women's "voice" (see id. at 39-45) to the content of women's erotica. There are manifestly sound reasons for this. Her goal of shaking her audiences with a comprehensive portrait of a coercive society demands a primary focus on the larger picture. She also knows how quickly a new perspective can be subverted by the attempt to answer a question framed in someone else's terms. Finally, she sees that the gradual unfolding of feminist understanding cautions against the conventional jurist's rigid link between right and remedy. It makes no sense to insist that feminists supply the means of rectifying every identifiable wrong when women may not yet be able to characterize the undominated world they seek, ${ }^{28}$ and only provisional solutions may be available. ${ }^{29}$

But should this choice satisfy feminist lawyers, who are willing to accept MacKinnon's account as descriptive of some important segment of women and beneficial for most women, yet can't always understand what it

25. See supra at 12-14.

26. In the area of pornography, for example, she challenges the applicability of the traditional First Amendment paradigm with a broad-brush (if interesting) argument. See FU at 206-13 (arguing that women have been excluded from the Constitution, that the First Amendment has historically protected the speech of the comparatively privileged, and that the First Amendment has become a "sexual fetish" through the subliminal suggestion of such publications as Playboy that its defense is essential to protect the masturbatory use of pornography).

27. See FU at 220 (describing her unrewarded faith in Judge Sarah Evans Barker [the district court judge who struck down the Indianapolis antipornography ordinance] as a "triumph of hope over experience").

28. This theme echoes throughout Feminism Unmodified. MacKinnon presents it most graphically in a speech entitled "Difference and Dominance" at 45, where she states, "I say, give women equal power in social life. Let what we say matter, then we will discourse on questions of morality. Take your foot off our necks, then we will hear in what tongue women speak."

29. In Feminism Unmodified, MacKinnon seems satisfied to present solutions in progressively greater detail-precisely as they emerge. One can see such an evolution in the section of the book which addresses the question of pornography. In the earliest two lectures, given in 1982, MacKinnon explains the harm of pornography and the extreme partiality lurking behind the ostensible neutrality of the First Amendment but does not specifically propose a remedy. In the next lecture, given in 1983, she articulates a specific legal theory of pornography as a violation of women's rights and compares it to the legal theory of obscenity, yet she does not explain how women whose rights have been violated can seek redress. In the following lecture, presented in 1984, MacKinnon refers specifically to the Minneapolis AntiPornography Ordinance and explains why it is constitutional. 
means for the quotidien choices we make in our lives? What are we to think of her insistence on framing and setting the boundaries of all discussion? While it is undeniable that women have been forced to answer on others' terms, often at great cost, I wonder if you can persuade without responding to people's reservations, or if you can adhere to so vast a theory without striving to fit it regularly to the concrete world in which you live. Do these reservations simply "express the male supremacist structure" instead of subverting it? Maybe. But I think not.

Answering a question in terms that another person-male or female - can understand can be a reflexive product of long-standing subordination. But it can also be an other-respecting form of human communication and an effective instrument of persuasion. It is, moreover, not always inimical to the cause of radical change. Even those well socialized to the assumptions of liberal legalism hold a range of potentially conflicting premises-including some born of insecurity or subordination-which might be mobilized to generate reformist zeal. ${ }^{30}$ Legal conventions such as argument by analogy or precedent can be the instruments for legitimating oppression, but they can also be important means of highlighting and exploiting shared premises. ${ }^{31}$

Furthermore, in many situations MacKinnon (and other feminist lawyers) confronts, the "interlocutors" pressing tactical questions are not hostile listeners but other feminist reformers. Unless one views the entire population as a potential enemy, the risk of responding to the assumptions of another is relatively low. MacKinnon might say that her reluctance to take her questioner's terms does not deprive her of a remedial program. She contends that "no more" is a programmatic statement, that seeing women's reality is knowing what needs to be done about it. In some sense this seems true: the magisterial set of proposals that end Toward a Feminist Theory of the State (at 245-47) seem a natural and surprisingly concrete outgrowth of her theory. But these proposals make for a convincing answer only if you are free to remake the world from the bottom up. ${ }^{32}$ Many

30. Joseph Singer, "Persuasion," 87 Mich L Rev. 2442 (1989) (explaining how author persuaded a class of law students to acknowledge an employee's reliance interest in her job by analogizing to the students' expectation that they would be permitted to graduate).

31. This position has been espoused by critical race theorists and other progressive proponents of change on behalf of subordinated groups. See note 3 supra. At times, MacKinnon seems to understand this as well. In some arguments about pornography, she draws explicit parallels between the new anti-pornography ordinance and the now-recognized Title VII claim for sexual harassment, an analytic move which invokes both analogy and legal precedent. See, e.g., FU at 198.

32. With respect to sex equality, MacKinnon states, "The intent requirement would be eliminated. The state action requirement would weaken. No distinction would be made between nondiscrimination and affirmative action. Burdens of proof would presuppose inequality rather than equality as a factual backdrop and would be more substantively sensitive to the particularities of sex inequality." Id at 247. These are wonderful, concrete descriptions of an end state many feminists would support. But they are also descriptions of a legal terrain on which many battles have been recently fought and lost. How feminist 
of us are not. We must speak to narrow-minded judges, represent battered women, ${ }^{33}$ handle law firm interviewers who harass our female students. Embracing a critique as comprehensive as MacKinnon's presents us with dozens of situations each day that from our present, time-limited, politically compromised position demand response. Some discussion of what a theory of gender subordination means in these contexts is essential-and it is not regularly forthcoming., 34 In describing MacKinnon as a "grand theorist" of feminism, Frances Olsen reasonably suggests that each theorist is not obliged to address all parts of a political agenda. ${ }^{35}$ But at times, MacKinnon's dominance theory seems so relentlessly separate from daily tactical concerns that I wonder whether her approach offers feminist lawyers more than (substantial) political inspiration. Methodologically speaking, it seems unlikely that the juxtaposition of an alternative framework, unalloyed by efforts at integration or analogy, can be a sufficient answer for a theory that claims to be the only "feminism."

Yet the difficulty with embracing MacKinnon's methods is not simply that her account of women's experience is too unitary to share or that her vision of feminist change is presented in a noncontextualized, or nondialogic, manner. It may be that her model of the feminist lawyer's life is impossible to emulate. Here the insight that what one makes of one's legal practice is in part a function of one's individual character seems to have particular resonance. MacKinnon's career as a revolutionary legal polymath is almost sui generis. Some feminist lawyers may lack the access and visibility that permit us to spread the word in forums all over the country; others may lack a professional role that confers such freedom from the urge to accommodate. But what most of us lack is the temperament that permits us to transform our professional lives into one scorching, unyielding accusation. MacKinnon might answer that it is not so

lawyers, presumably the agents of change she describes, would surmount these barriers is never discussed.

33. For a richly textured account of, inter alia, the numerous complex choices facing those who would characterize a battered woman at trial, see Christine Littleton, "Women's Experience and the Problem of Transition: Perspectives on the Male Battering of Women," 1989 U. Chi. LF. 23; Martha Mahoney, "Legal Images of Battered Women: Redefining the Issue of Separation," 89 Mich. L. Rev. (forthcoming 1991).

34. In fairness to MacKinnon, I should add that there is at least one public address during which I have heard her speak more responsively. On that occasion, MacKinnon addressed the question of whether Sports Illustrated's Swimsuit issue would be considered pornography, and advised female students about what they could do to respond to the display of centerfolds in nearby student lockers. The difference that may exist between MacKinnon in person and in print (or in printed versions of public addresses) may provide support for Frances Olsen's thesis about the strategic uses of what I have called rigidity. See Olsen, $89 \mathrm{Col}$. L. Rev. (cited in note 20). It may be that when MacKinnon writes for a broad and unidentified audience, she is more insistent on setting boundaries and maintaining the uncompromised purity of her position than when she speaks to a particular audience whose tenor and attitudes she can better gauge.

35. See Olsen, $89 \mathrm{Col}$. L. Rev. at 1166-77. 
much a question of temperament as a question of knowledge or will-and she might, to some extent, be right. But for feminism to deny itself the resources of any but those with her attributes would be needless and selfdestructive; and her example gives only limited guidance to those who seek to find another way.

\section{FEMINISM AND PLURALISM}

It is thus fortunate that MacKinnon represents one strong voice among many in the burgeoning world of feminist legal change. Many feminist lawyers, buoyed in part by the breadth of MacKinnon's challenge, have pressed forward with their own efforts to recast law reform. Most of these feminists share one or more of MacKinnon's premises: that the vaunted "neutrality" of liberal legalism disguises the inevitable perspectivity of legal rules, ${ }^{36}$ that women's perceptions and experiences must be the starting point for reforming gendered legal rules. Yet they also hold premises that distinguish their work from "dominance" feminism, and this has had important implications for their contributions to legal method. Few of these activists share either MacKinnon's unitary view of women's experience or her sense that the adaptation of her theory to the challenges of a compromised world risks distortion and misunderstanding. Their rejection of these premises means not only that these feminist lawyers have been able to avoid the methodological limitations described above but also that they have been able to pursue more freely the multiple methodological directions in which the insights of feminist theory seem to point. In the section which follows, I will examine the methodological difference these starting points make and then ask why the methodological multiplicity we see in this body of work might be a desirable development for feminist lawyering and feminist legal change.

\section{The Difference Difference Makes}

Many feminist lawyers have expressed doubt that women's experiences can be adequately captured by a formulation as unitary as MacKinnon's "use and abuse." 37 They argue that women's experiences vary, along axes that are partly individual but also shaped by such factors as

36. By "perspectivity" I mean the quality of having been formulated from some identifiable, partial, human perspective. Liberal legal discourse does not often acknowledge this characteristic of legal rules, arguing instead that they are formulated from a neutral or objective position, which (depending on the account) maintains a clarifying distance from any identifiable perspective, or adequately comprehends all (relevant) perspectives, rather than partaking of any one.

37. See, e.g., Martha Minow, "The Supreme Court, 1986 Term-Foreword: Justice 
race, class, and sexual orientation. ${ }^{38}$ They are reluctant to describe as "false consciousness" a woman's account of her experience that departs from their characterization or reflects the assimilation of some male-created norms. ${ }^{39}$ These premises complicate both the description of women's experience(s) and the relationship between gender and other categories through which difference is socially constructed..$^{40}$ While these differences in the substantive account of women's experiences have themselves become a topic of spirited feminist debate, I raise them in order to ask a methodological question. What has the perception of women's experiences as plural and complex meant for the way that feminists argue as lawyers and for the critical gaze they cast on the organization or conduct of their profession? ${ }^{41}$

Looking back to the categories of "lawyering method" with which we began, we can ask first about forms of argumentation or persuasion. One instructive difference can be found in the way proponents attempt to expose the invisible perspectivity of the law. MacKinnon challenges aperspectivity by juxtaposing a unitary and comprehensive "feminist perspective" created by women's experiences of "use and abuse." Such feminists as Martha Minow also rely on systematic juxtaposition as a critical technique. However, they argue that the juxtaposition of a unitary "feminist" perspective misrepresents a world of experiences that are actually diverse and imposes the same devaluation on those outside its confines that liberal legalism has historically imposed on women. ${ }^{42}$ Instead, these feminist lawyers advocate multi-perspectivity-the juxtaposition of a range

Engendered," 101 Harv. L Rev. 10 (1987); Schneider, et al., 10 Women's Rts. L Rptr. (cited in note 2); Colker, 13 Harv. Women's L.J. (cited in note 2).

38. See, e.g., Harris, 42 Stan. L. Rev. (cited in note 22); Kimberlé Crenshaw, "Demarginalizing the Intersection of Race and Sex: A Black Feminist Critique of Antidiscrimination Doctrine, Feminist Theory and Antiracist Politics," 1989 U. Chi. LF. 139; Patricia Williams, "The Obliging Shell: Some Informal Comments on Formal Equal Opportunity," 87 Mich. L. Rev. 2128 (1989). One of the most comprehensive and insightful articulations of this position may be found in Elizabeth V. Spelman, Inessential Woman: Problems of Exclusion in Feminist Thought (Boston: Beacon Press, 1988). Spelman is not a lawyer but rather a philosopher who writes thoughtfully and provocatively about legal issues. For a different but not necessarily incompatible perspective on "anti-essentialism" in feminist legal thought, see Fineman, 42 Fla. $L$ Rev. (cited in note 1).

39. See Bartlett, 103 Harv. L Rev., and Minow, 1989 U. Chi. LF. (both cited in note 1); Mari Matsuda, "Pragmatism Modified and the False Consciousness Problem," 63 S. Cal. L. Rev. 1763 (1990).

40. See sources cited in note 38 .

41. One obvious consequence of this complex view of women's experience and gender discrimination is that the lawyers who hold it take a broader view of the clients and constituencies toward whom their efforts should be directed. They might describe their perspective or their legal methods as "feminist," but many of these lawyers employ their methods on behalf of groups not distinguished solely or even primarily by their gender. Mary Dunlap argues on behalf of gays and lesbians; Patricia Williams addresses issues of race and class; Martha Minow focuses on groups from special needs children to minority religions.

42. See Minow, 101 Harv. L. Rev.; Minow "Feminist Reason, Getting It and Losing It," 38 J. Legal Educ. 47 (1988). 
of perspectives-which shows the dominant legal rule to be elevated by the power of its adherents rather than by the "naturalness" of its perspective, yet refrains from reifying, or perpetuating hierarchies among, the voices of the excluded. ${ }^{43}$

A belief in the multiplicity of women's experiences has not only influenced the elements of critical argumentation, it has also affected the ways that feminist lawyers organize and express themselves to secure legal change. Mary Dunlap has endorsed multiperspectivity as a way to avoid marginalizing stigmatized members of a legal coalition. She argues, for example, that considering a variety of perspectives might have prevented the lead counsel in Bowers v. Hardwick ${ }^{44}$ from relating the right to sexual privacy to the home, a view which neglected the perspective of gays and lesbians and undercut the credibility of amici such as Lambda Legal Defense Fund. ${ }^{45}$ Martha Minow has formulated a method for communicating such multi-perspectivity to appellate courts. She has presented the sometimesdiverging statements of her multiple clients in her briefs. In Webster $v$. Reproductive Health Services, for example, her brief for 36 prochoice religious groups included short statements by many of those groups offering their own perspectives on abortion and religious conscience. ${ }^{46}$ Although this approach is obviously not appropriate in every case, ${ }^{47}$ it offers tangible communicative and strategic advantages. The sheer multiplicity of the al-

43. One feature that distinguishes Minow's approach is that for her, feminism is deeply connected to what she describes as the "dilemma of difference" affecting a range of groups. Women are subordinated because men enjoy the power to make their own lives and views the norm-a perspective so dominant and pervasive as to appear to be no perspective at all-and to label women, who diverge, as "other." In the same way, whites enjoy the power to make blacks "other"; the able-bodied define and marginalize those with disabilities; heterosexuals generate norms and institutions that stigmatize lesbians and gay men. So long as the dominant groups maintain this pervasive power to define, the victims of discrimination are confronted with a perverse dilemma: both ignoring and calling attention to one's difference risks perpetuating the stigmatization. See Martha Minow, "Learning to Live with the Dilemma of Difference: Bilingual and Special Education," 48 Law \& Contemp. Prob. 157 (1985); Minow, 101 Harv. L Rev.; Martha Minow, Making All the Difference: Inclusion, Exclusion and American Law (Ithaca NY: Cornell University Press, 1990).

44. 106 S. Ct. 2841 (1986).

45. In Schneider et al., 10 Women's Rts. L. Rptr. at 122 (cited in note 2).

46. See Brief Amicus Curiae for American Jewish Congress et al., Webster v. Reproductive Health Services, 492 U.S. 490 (1989). Minow served as counsel of record for these groups and wrote the brief with Professor Avi Soifer of Boston University Law School.

47. This approach would seem to require a case in which at least two things are true: (1) the attorney represents multiple litigants, with interests and perspectives which are not identical; and (2) the litigants are capable of offering a clear articulation of the broader substantive commitments underlying their legal position. However, Minow does not appear to take a restrictive view of the legal contexts to which this approach might be applied. For example, she advocates interviewing individual clients who are members of victimized groups and integrating their statements in the appellate brief. She notes, for example, that this strategy was not but might profitably have been used to communicate the perspectives of high school students suffering censorship of their school paper in Hazelwood School Dist. v. Kuhlmeier, 484 U.S. 260 (1988). Telephone conversation with Martha Minow, June 22, 1989. 
ternative perspectives presented makes the dominant understanding appear less natural or necessary, and more the contingent product of one group's power to make its perspective the norm. Moreover, the practice of presenting multiple views eliminates the need to assimilate one group's perspective to that of others, and is more productive of equal partnerships than of solipsistic alliances. 48

Feminist lawyers who take a plural view of women's experience have also offered new conceptions of the roles and relationships among legal actors. They have done so in part because of the looser relationship they conceive between experiential arguments and specific substantive perspectives. For MacKinnon, invocation of women's experience inevitably points to patterns of "use and abuse." But for feminists who do not see an inevitable substantive connection, experience can function not only as a source of substantive information but as a way of knowing that can create new relationships among actors in the legal system. The work of Elizabeth Schneider provides an example of the directions such reformulation has taken. 49

Schneider argues, first, that feminist lawyers can use their own experiences to assist in the translation of a client's perspective. She notes that her own experiences as a woman led her to believe that Yvonne Wanrow's claim of self-defense might not be understood by a conventionally instructed jury..$^{50}$ This perception led her to advocate an instruction requiring individuation in the jury's consideration of her claims. ${ }^{51}$ While

48. Some feminists and critical race scholars have argued that this kind of multiple, or "multivalent," perspective may exist within the perceptions of individuals or ostensibly homogeneous groups, particularly those who may have experienced intersecting patterns of subordination, as well as among heterogeneous groups. See Mari Matsuda, "When the First Quail Calls: Multiple Consciousness as Jurisprudential Method," 11 Women's Rts. L Rptr. 7 (1989). These scholars have argued that this individual or internal form of multi-perspectivity can be used to shape legal rules or inform the thought processes of legal decision makers such as judges. See Williams, 87 Mich. L Rev. at 2151 (cired in note 38). Although I find the use of multi-perspectivity in legal decision making and reconstruction a promising possibility, I think more work needs to be done elaborating the kinds of understandings or prescriptions that are likely to flow from this approach.

49. The following examples come from Schneider et al, 10 Women's Rts. L Rptr. (cited in note 2), but other accounts of these and similar approaches can be found in Elizabeth Schneider, "The Dialectic of Rights and Politics: Perspectives from the Women's Movement," 61 N.Y.U. L. Rev. 589 (1986); id., "Describing and Changing: Women's Self-Defense Work and the Problem of Expert Testimony on Battering," 9 Women's Rts. L Rptr. 195 (1986).

50. Yvonne Wanrow was a Native American woman, impeded by an injured leg, whose act of violence was perpetrated in an attempt to protect her children from an intruding white man who she believed had previously threatened them. Schneider's own experience as a woman led her to fear that a conventionally instructed jury would not understand the factors that led Wanrow to perceive imminent danger, which included her gender-related sense of herself as physically vulnerable and the tension in her community between whites and Native Americans. Schneider was concerned that the jury would be more likely to see Wanrow's self-defense as "hysterical" or "emotional" than as reasonable. Schneider et al., 10 Women's Rts. L. Rptr., at 114-15.

51. Id at 115-16. Schneider warns that a lawyer must resist the temptation to confuse 
Schneider enlists the perspectives of women as the primary basis for the reform of legal rules, she asks the jury to consider not "women's experience" but the experience of a particular woman, and she arrives at this demand by considering the relationship between her client's experience and her own.

Schneider also contends that lawyers can profitably, if more cautiously, draw on the experiences of other participants in litigation, including judges themselves, to facilitate understanding and agreement. In State v. Kelly, ${ }^{52}$ for example, Schneider was asked to argue as amicus that the testimony of an expert on "battered women's syndrome" should be admitted. In preparing the case, Schneider uncovered an opinion by New Jersey's Justice Wilentz in a case where the defendant had killed his wife. Although nothing in the record gave a reason for this act, the justice supplied an explanation that made some sense of the man's actions. Schneider felt that the battered women's expert would, in fact, provide a similar function for the defendant in State v. Kelly. Against the advice of her colleagues, she spoke directly to the justice during oral argument, invoking the comparison to help him understand the need for an expert to explain the woman's actions to the jury. Justice Wilentz responded with an thoughtful and broad-ranging opinion admitting the expert testimony. ${ }^{53}$ This approach conceives of judges not as a detached purveyors of justice but as human beings with their own store of experiences-even partisans willing to act on their own intuitions. Moreover, they are reminded of these additional attributes by the attorney, who steps out of her role of formal deference to establish a moment of human connection and, ideally, shared understanding. Although it is a risky technique that Schneider does not routinely recommend, it can be a valuable tool for mobilizing those often-dormant portions of judges' own experiences that may make them more receptive to the experiences of women.

Feminist lawyers who take a plural view of women's experiences have also reshaped the roles of legal participants by highlighting specific experiential perspectives that dominance feminists such as MacKinnon reject. One such perspective is the importance many women have placed on care and relationship in their lives. This perspective, which was brought to popular attention by the work of Carol Gilligan, ${ }^{54}$ is discounted by MacKinnon as an artifact of oppression. ${ }^{55}$ Yet for those who ascribe to this

her experiences with her client's, id. at 117. Yet she concludes that a common strand in a lawyer and client's experience, if the lawyer is willing to trust the intuition it provides, may materially improve the process of representation.

52. 84 N.J. 305, 419 A.2d 406 (1980).

53. Schneider et al., 10 Women's Rts. L Rptr., at 137-38. 1982).

54. Carol Gilligan, In a Different Voice (Cambridge, Mass.: Harvard University Press,

55. See FU at 39. With a characteristic mixture of appreciation, cynicism, and exasperation, MacKinnon states (id.): 
focus a more complicated etiology, or those who find its potential for good more important than its origins in oppression, this emphasis on connection and mutual responsibility ${ }^{56}$ provides an important tool for recasting professional relationships. Some of the earliest and most encompassing work in this vein was done by Carrie Menkel-Meadow, who asked how a relational focus might alter the adversary norms of our legal system. ${ }^{57}$ More recently, feminist lawyers merged this focus with a concern about subordination in relationship, and have begun to ask how to engender mutual respect and/or prevent subordination within the relationships that comprise a lawyer's professional life.

Lucie White, for example, has explored the ways in which the relationship between the attorney and the client can exacerbate or ameliorate the client's feelings of subordination. White counsels attention to the way a client prefers to frame her story and highlights the drawbacks of strategies that can place the client in a posture of supplication. ${ }^{58}$ Ruth Colker, on the other hand, has focused on the relationships among lawyers created by the process of litigation. ${ }^{59}$ Colker argues that litigation provokes an argumentative posture in which lawyers neither approach each other's claims in good faith nor attempt to learn from each other's perspectives. As feminists lawyers, she argues, we should be committed to establishing a more dialogic relationship with one another. ${ }^{60}$ Particularly in controver-

\footnotetext{
Women have done good things, and it is a good thing to affirm them. I think quilts are art. I think women have a history. I think we create culture. I also know that we have not only been excluded from making what has been considered art; our artifacts have been excluded from setting the standards by which art is art. Women have a history all right, but it is a history both of what was and of what was not allowed to be. So I am critical of affirming what we have been, which necessarily is what we have been permitted, as if it is women's, ours, possessive. As if equality, in spite of everything, already ineluctably exists.
}

56. The response of these feminists to MacKinnon's position is that even qualities born of oppression, so long as they are understood, may be used to reform male-structured environments. I have sometimes taken this position myself with respect to restructuring the workplace. See Kathryn Abrams, "Gender Discrimination and the Transformation of Workplace Norms," 42 Vand. L. Rev. 1183 (1989). I am in this respect sympathetic to the view expressed by Simone deBeauvoir, who spoke of "feminine qualities which have their origin in our oppression but should be preserved after our liberation." See Simone de Beauvoir, The Second Sex 153 (New York: Vintage Books, 1974).

57. See, e.g., Carrie Menkel-Meadow, "Excluded Voices: New Voices in the Legal Profession Making New Voices in the Law," 42 Miami L Rev. 29 (1987); id., "Portia in a Different Voice: Speculation on a Women's Lawyering Process," 1 Berkeley Women's LJ. 39 (1985).

58. See Lucie White, "Subordination, Rhetorical Survival Skills, and Sunday Shoes: Notes on the Hearing of Mrs. G.," 38 Buff. L Rev. 1 (1990) (explaining dilemma over whether to use estoppel claim, which permitted client more dignity but threatened to alienate hearing officer, or "life necessities" claim, which stood better chance of success but placed client in posture of supplication). White's analysis is mainly context-specific, and she primarily alerts lawyers to this tension in representing their clients, rather than advising them in general terms as to how to resolve it.

59. Colker, 13 Harv. Women's LJ. (cited in note 2).

60. Colker argues that dialogue is feminist in numerous respects: in its association 
sial cases such as those involving abortion, it is crucial to instill in litigation the seeds of dialogue: a concern for and willingness to consider the interest raised by the opposing side.

A complex and plural view of women's experiences is not the only factor that has shaped the methods of feminist lawyers in ways that diverge from MacKinnon's example. Feminist lawyers have also questioned MacKinnon's reluctance to adapt her theory to the challenges of daily life or to frame her perspectives so that they are more accessible to the uninitiated audience. There are several reasons for this view. Some feminist lawyers feel that the test of a feminist theory lies in its ability to adapt to practical challenges in the field. Others believe that an effective synthesis can be achieved by experimenting with the practical meaning of a theory and using the lessons learned from early applications to refine the understanding of the theory itself. ${ }^{61}$ Still others suggest that taking as a starting point the discriminatory norms of institutions and individuals is a necessary evil in achieving persuasion and change. When this adaptive, practical strain in feminist thinking has been combined with a belief in the pluralism of women's experiences, ${ }^{62}$ it has produced distinctive strategies for reform-both of substantive laws and of legal institutions.

The difference these premises can make is exemplified in the work of Christine Littleton. ${ }^{63}$ Littleton's work is of particular interest because she starts from MacKinnon's premise that "believing women's accounts" is central to resisting "phallocentrism" of our law and society. However, two features of Littleton's work make her application of the injunction to "believ[e] women's accounts" different from MacKinnon's. First, "believing women's accounts" means hearing more than stories of "use and abuse by men." It means examining the range of accounts that women give of their gender-specific injuries and asking what it would mean for the legal system if we took all these accounts-including those that may embarrass or anger us-seriously. Taking up the often-asked question of why women fail to leave battering partners, Littleton looks not only at the socially acceptable reasons such as fear or economic constraint, but at the feelings of love and the desire for connection that bind some women to men who batter them. A woman who loves or seeks connection with a batterer is not a woman

with consciousness raising and in its capacity to illuminate difference, and in its accommodation of an ongoing effort to understand one's position in society. Id. at 143-44. To my mind, this does not so much establish that dialogue is feminist, as that dialogue, which Colker properly values for a variety of reasons, is consistent with certain feminist precepts.

61. See Schneider, 61 N.Y.U. L. Rev. (cited in note 49).

62. By examining the methodological consequences that issue when feminist lawyers begin from both of these premises, I do not mean to suggest that they are inevitably paired in the professional understandings of feminist lawyers. It is possible, for example, to have a more singular view of women's experience combined with a practical, adaptive approach to the reform of legal institutions. See, e.g., Menkel-Meadow, Berkeley Women's LJ.

63. See Littleton, "Women's Experience and the Problem of Transition: Perspective on the Male Battering of Women," 1989 U. Chi. L.F. 23. 
whose account would be credited by MacKinnon, but for Littleton her account raises an interesting possibility: ${ }^{64}$ that it is not women's hopes and aspirations that require change, but the larger world to which these attitudes respond. The desire for connection would not be peculiar or selfdestructive if batterers could be reformed or if women could strike out on their own in search of safer relationships. Looking clearly at even the most discomitting accounts offered by women permits Littleton to address these possibilities.

When Littleton envisions the world which would make possible safe(r) connection for women, she is neither visionary nor uncompromising in her approach. This is the second quality that distinguishes her remediation from MacKinnon's. Despite the fact that her aspiration is surprisingly large, Littleton's proposals are not uniformly comprehensive, nor are they neglectful of the immense attitudinal barriers that will impede reform in this area. Instead, they are resourcefully plural, as to both the scope of the change they recommend and the extent to which they accommodate attitudinal intransigence. While some of her proposals-such as addressing the wage gap, which prevents women from making credible threats to leave ${ }^{65}$ - are comprehensive in character, others-such as conditioning the batterer's diversion from the criminal justice system on completion of rather than entry into a course of therapy ${ }^{66}$-would produce change through a focused revision of existing programs. Similarly, when Littleton asks how the state might legitimate forms of connection less risky than heterosexual marriage, some of her solutions, such as the legalization of gay marriage, ${ }^{67}$ demand a comprehensive change in social attitudes, while others, such as an expansion of the shelter movement to create group living arrangements for women, ${ }^{68}$ take popular attitudes as she finds them rather than trying to recast them from the ground up.

The combination, exemplified by Littleton, of remedial responsiveness and a plural view of women's experiences has also produced provocative efforts at institutional reform. Interesting examples of such efforts may be found in the work of Martha Mahoney and Lucie White. These

64. Littleton stakes out a position she identifies as falling between a "false consciousness" rejection of certain women's accounts and an uncritical, relativistic acceptance of all women's stories. She argues that we should view women's descriptions of their experiences as "accurate, reasonable and potentially understandable given the conditions under which we live." Id at 27. This view, which involves "a dialectic between our own descriptions of our varying experience and the conditions under which such descriptions are made" (id.), seems distinct from MacKinnon's contention that immersion in the material conditions of women's lives can produce only one account of women's experience. It bears closer relation to the epistemological "positionality" recently articulated by Katharine Bartlett, 103 Harv. $L$ Rev. at 880-88.

65. Littleton, 1989 U. Chi. L.F. at 54.

66. Id. at 53 .

67. Id. at 55.

68. Id at 56. 
feminist lawyers begin from the premise that women's intransigently diverse accounts of their experience cannot be easily synopsized; it therefore becomes crucial that they be presented in a legal setting in which they are likely to be heard and credited. Because the courtroom setting is, at present, a flawed forum for such presentation, they have attempted to reform it to make contextual, credible presentation by women possible. Mahoney suggests that certain rules of evidence make it difficult for battered women to tell their stories. ${ }^{69}$ The requirements of relevance and responsiveness often make it difficult for women to create a picture of a complex relationship, which is often best depicted through a nonlinear narrative. Mahoney urges lawyers to reassess the scope of these requirements in settings where their rigor may be distorting. White contends that differences in the speech patterns of dominant and subordinated groups lead fact finders to devalue accounts of women, minorities, and those of lower socioeconomic status. ${ }^{70}$ Drawing on literature from several disciplines, she raises a range of ameliorative possibilities, from jury instructions or expert testimony, which might apprise fact finders of the risk of devaluation, to changes in the structure of trials or hearings that might eliminate the devaluing. ${ }^{71}$ These efforts manifest a distinctive posture for advocates of progressive reform: It is the need to communicate women's perspectives rather than the existing features of these institutions that advocates take as a given. While these feminist advocates accept conventional legal institutions as a primary means for implementing proposed reforms, they also attempt to reform those institutions in ways that will make them more responsive-not to a single "feminist perspective" but to the needs of women to communicate their diverse experiences.

A similar set of premises animate the efforts of Martha Minow to reassess the process of judging. In contrast to MacKinnon, who relies on judges (see $F U$ at 220) to enforce her statutory schemes, but gives little thought to changing their institutional roles, ${ }^{72}$ Minow is persistently concerned with challenging the ways judges think. Amplifying unheard voices is insufficient if legal decision makers fail to acknowledge the existence and effect of their particularized perspectives. And for judges-who are often white, middle-class men-Minow sees such failure as uniquely probable. Not only does the pervasiveness of their perspective make it appear "perspectiveless," but norms that encourage judges to find rather than make

69. See Mahoney, Mich. L Rev. (cited in note 33); see also White, 38 Buff. L. Rev. at 56.

70. See White, 38 Buff. $L$ Rev. at 6-19 (cited in note 58 ).

71. Id. at 55-57. For a fascinating theoretical exploration of how several assumptions of feminist theory might help us reconstruct procedural due process see Cynthia Farina, "Conceiving Due Process," Yale J.L \& F Feminism (1991, forthcoming).

72. Perhaps MacKinnon takes as her model the gradual education of the courts to the claim of sexual harassment, and she assumes that as society begins to understand her claim, judges will act accordingly. 
law, or to distance themselves from the lives of those before them exacerbate this stance. ${ }^{73}$ Thus, crucial to Minow's lawyering task is the development of a judiciary that glimpses the partiality of its own perspectives and the common humanity it shares with the litigants before it.

Minow has addressed this task by advancing innovative criteria for judging ${ }^{74}$ and by educating judges through the Doing Justice program at Brandeis University. The Doing Justice program uses the liberal arts to offer judges new perspectives on their tasks, but, more important, it focuses their attention on the attitudes and assumptions that shape their adjudication. Minow describes a discussion in which she used Mary Gordon's short story, "Violation" to help judges explore the feelings of a victim of sexual assault. ${ }^{25}$ In the story, the narrator describes the two rapes she has suffered in her lifetime, one at the hands of a stranger, another committed by an uncle. Minow asked the judges to describe the tone in which the narrator gives this account and to consider why the narrator never reported either assault. She notes that, through this exercise, judges who tended to be impatient with the ambivalence of victim/ witnesses in domestic assault cases began to grasp the anguish these crimes can produce.

Like many law reformers, Minow attempts to change the way judges approach the questions before them. Yet she does so by approaching them as human beings, through a process that resembles consciousness raising. The experiences of gender subordination are not, in most cases, the judges' own: these are imported into the discussion through the vehicle of fiction. But their own experiences-of uncertainty, ambivalence, frustration with the limitations of their own role in resolving it-also form the grist of discussion. By collective reflection on the intersection of these difficulties, judges can reexamine the attitudes that prevent them from grasping women's injuries or taking responsibility for the choices necessary to ameliorate them.

\section{MULTIPLICITY AND METHOD}

Even more striking than the extent of methodological innovation among feminist lawyers are the many different directions it has taken.

73. See Martha Minow \& Elizabeth V. Spelman, "Passion for Justice," 10 Cardozo L. Rev. 37 (1988); Minow, 101 Harv. L. Rev. (cited in note 37).

74. See Minow \& Spelman, 10 Cardozo L Rev.; Minow, 101 Harv. L. Rev. These articles are part of a larger discussion among feminist jurisprudes about the value of objectivity in judging. See, e.g., Judith Resnik, "On the Bias: Feminist Reconsiderations of the Aspirations for Our Judges," 61 S. Cal. L Rev. 1877 (1988); Patricia Cain, "Good and Bad Bias: A Comment on Feminist Theory and Judging," 61 S. Cal. L Rev. 1945 (1988).

75. See Minow, "Words and the Door to the Land of Change: Law, Language and Family Violence," 43 Vand. L. Rev. 1665 (1990). 
Some innovators have questioned the norms of persuasion, while others have found new ways of expressing or translating the voice of the client. Some have used experience to expose the partiality of substantive rules, while others have used experience to raise the consciousness of judges. While there are certain themes threading through these efforts-the value of experiential forms of knowing, the perspectivity lurking behind the "neutrality" of law, the relation between the substantive perspectives embodied in legal rules and the practices and procedures used to adjudicate them-there is no conceptually unified set of methodological reforms one could easily identify as "feminist." One might legitimately ask whether there is value in this multiplicity, or whether feminists might be better served by a more unitary approach to the methods as well as the substance of feminist legal change. This multiplicity will doubtless prevent feminist lawyers from uniting behind a discrete set of methodological innovations. It may also tax the patience or evade the understanding of observers who are sympathetic to some premises of feminist legal change but do not immediately grasp their import for legal practice. Yet I believe there is much to be said for the multiplicity of ways in which feminists have attempted to reconceive the lawyer's task, at least for the present. Several arguments lead me to this conclusion.

If we want to appraise the benefits of multiplicity in methodological innovation, we should begin by asking why feminists want to undertake such innovation in the first place. Sometimes feminists undertake methodological innovation for a purely pragmatic reason: it wins cases. ${ }^{76}$ Civil rights reformers may have employed common law, analogical reasoning as they moved from Gaines ${ }^{77}$ to Sweatt ${ }^{78}$ to Broun ${ }^{79}$ because they thought it presented the strongest likelihood of persuading the courts. Feminist lawyers may reject the traditional norms of legal persuasion for precisely the

76. Katharine Bartlett has written that to choose a legal method simply because it assures a particular result is to establish an "improper" relationship between substance and method, because it exerts no meaningful constraints on the decision maker. Bartlett, 103 Harv. L Rev. at 846-47 (cited in note 1). Although this proposition doubtless requires more qualification when it is transported from the realm of legal theory to that of legal advocacy, I do not mean to suggest that feminist lawyers have selected these methods only because they win cases. Lawyers believe that they have merit because they invoke an experiential epistemology that encourages judges to consider their own humanity or that of the litigants before them. But the determinative factor in many cases is that the lawyer's use of a particular method will make a legal decision maker more likely to understand the lawyer's substantive point.

77. Missouri ex rel. Gaines v. Canada, 305 U.S. 337 (1938) (state statute providing for black students to attend out-of-state law school where no state law school serving blacks was available violated the Fourteenth Amendment).

78. Sweatt v. Painter, 339 U.S. 629 (1950) (decision denying black student admission to white law school violated Fourteenth Amendment, where separate black law school was not equal).

79. Brown v. Board of Education, 347 U.S. 483 (1954) (system of public education based on premise of "separate but equal" education for black students violates Fourteenth Amendment). 
same reason. Elizabeth Schneider did not invoke the past experience of Chief Justice Wilentz simply because she was enamored of experiential argumentation; she did so because she believed there was no other way of making the judge understand the need for expert testimony. It may be, as MacKinnon suggests, that analogical reasoning and other traditional forms of argument are broadly unavailing for feminist persuasion, because the law, even in its aspirational forms, contains few norms that do not entail subordination. But it is true at least that in some subset of cases, feminists have been moved to challenge the norms of legal persuasion because without such a challenge they could not have succeeded in persuasion at all.

In other cases, however, the desire to change the norms that shape legal argumentation and decision making is animated by less immediate concerns. Some feminist lawyers have observed that the hidden perspectivity that mars the "neutrality" of substantive law also lurks behind the time-honored elements of legal method. Feminist lawyers have been assisted in glimpsing this connection by the critique of objectivity which has emerged in feminist legal theory as well as in the social and physical sciences. ${ }^{80}$ The norms of distance and abstraction that govern legal argumentation and decision making are no more "natural" or necessary than, for example, the application of the so-called reasonable person's perspective in sexual harassment cases ${ }^{81}$ or the official invocation of a "public/private" distinction in responding to spousal abuse. Like the perspectives expressed in the substantive law, the elements of legal methodology may be described as the values and practices of a particular group which enjoys the power to make its values the norm in the profession as a whole. For some feminist lawyers, the desire to take the critique of objectivity into the realm of method is a desire to show how deeply relations of power infuse even those institutions we are most likely to conceive as apolitical or "neutral."

In yet other cases, feminist lawyers have been bolstered by the insights of feminist theory to challenge features of the profession that have long been a source of concern among lawyers. Feminists are not the first to find fault with intense or unproductive adversariness among lawyers, with the social and emotional distance of lawyers from those clients whose claims they attempt to vindicate, or with judicial reluctance to take responsibility for affirmative choice among legal rules. ${ }^{82}$ Yet the insights of relational feminism or the critique of objectivity have supplied these lawyers

80. See, e.g., L. Nicholson, ed., Feminism/Postmodemism (New York: Routledge, 1990); L. Tribe, "The Curvature of Constitutional Space: What Lawyers Can Learn from Modern Physics," 103 Harv. L. Rev. 1 (1989); Rubin, "The Practice and Discourse of Legal Scholarship," 86 Mich. L Rev. 1835 (1988).

81. See Abrams, 42 Vand. L. Rev. at 1197-1209 (cited in note 56) (critiquing use of gender-neutral "reasonable person" standard in hostile environment sexual harassment cases).

82. A variant of this point is made by Jane Cohen, 25 Tulsa L.J. at 732-33 (cited in note 2). 
with new tools that affirm their critical intuitions, and provided them with norms with which to mount a critique or generate alternative practices.

The variety of reasons for methodological innovation itself supports a multiplicity of responses. If methodological innovations must be judged according to the context in which they are attempted, the reasons for innovating form an important part of that context: ${ }^{83}$ a variety of goals might justify a variety of formulations. Practice might be expected to vary as well. But one need not see these reasons as various to perceive the merits of multiplicity. Several of the individual reasons for innovation are also served by a diversity of methodological responses.

If feminist methodological innovation is undertaken to advance the cause of feminist legal change-either by benefiting the claimant in a particular case or by preventing the substance of feminist proposals from being diluted-a pluralism, one might even say agnosticism, about the most advantageous forms of innovation seems to be an appropriate response at present. It is probably too early to tell which innovations will prove effective for clients, which will prove sufficiently resilient to revise the norms of legal argumentation or professional organization rather than being eroded by them. Pressing the professional implications of feminist theories in a variety of different directions seems an appropriate and productive response to this inevitable phase of uncertainty. ${ }^{84}$ Similarly, if challenging the necessity, naturalness, or neutrality of the methodological norms that govern legal decision making is a recurrent theme in many of these efforts, the juxtaposition of multiple alternatives, as Martha Minow has made clear in the realm of substantive law, may be the most effective way to expose the dynamics of power and choice.

To see the benefits of multiplicity in method, however, is not to reject the contribution of those such as Catharine Mackinnon who advocate a more unitary approach to understanding and characterizing women's situation. For MacKinnon's work is not devoid of its own multiplicity-multiplicity that comes from recreating the lawyer as a polymath, and challenging the numerous processes that shape the formulation of law. It

83. Here I rely on an approach to evaluating the "truth" of feminist claims that resembles the "positionality" articulated by Katharine Bartlett, 103 Harv. L. Rev. at 880-87.

84. Certainty about optimal methods is bound to be elusive even in the long run because "advancing the goals of feminist legal change" is bound to be understood differently by different reformers, and some approaches are likely to succeed at some times and fail at others. However, sustained application of different innovations is likely to yield insights not evident from the outset, as has been the case with the proposal of relational feminists that alternative dispute resolution mechanisms might serve the interests of women in situations involving domestic violence. Sustained use and inquiry in this area seem to have yielded the insight that informal dispute resolution mechanisms, though responsive to important norms of relational feminism, raise a high risk of importing power inequalities, unmoderated by formal procedural protections, into the process of dispute resolution. See Lisa Lerman, "Mediation of Wife Abuse Cases: The Adverse Impact of Informal Dispute Resolution on Women," 7 Harv. Women's L.J. 57 (1984). 
simply remains to others to provide the multiplicity that arises from taking a plural view of women's experience, exploring experiential methodology beyond its connections to particular substantive outcomes, and responding with varying levels of remedial accommodation to an attitudinally compromised world. To regard MacKinnon's work in this way, as continuous with that of other feminist innovators, is not to see her work as she sees it herself: as having created the only "unmodified" feminism. But it is to see it in a way that may hold out promise for legal change. By weaving MacKinnon's insights with those of other legal feminists, we may begin to create a legal culture in which feminists are devalued neither for their substantively divergent message nor for the methods through which they choose to offer it. 